\title{
THE DEPICTION OF WOMEN IN THE SELECTED NOVELS OF NAGUIB MAHFOUZ
}

\author{
Manal Hussein Ali Nukhrah ${ }^{1 i}$, \\ Ali Naji Gahlan Muthanna², \\ Mirza Sultan Biag ${ }^{3}$ \\ 1\&2Research Scholar, \\ School of Languages, Literature \& Cultural Studies, \\ Swami Ramanand Teerth Marathwada, University, \\ Nanded, India \\ ${ }^{3}$ Research Supervisor, \\ Associate Professor \& Head Dept. of English, \\ Indira Gandhi Sr. College (IDCO), \\ Nanded, India
}

\begin{abstract}
:
This paper represents the female factor and discusses the depiction of women in the view of the novelist. The paper also focuses on the concept of feminism in the era of Mahfouz and portrays a micro picture of women in Arabian society. Mahfouz attempts to examine in his novels male dominance and female resistance in Arabic society, mainly in Egypt and how women have been marginalized and relegated as secondary to men through the established traditions. The study also focuses on how women respond to these attitudes within the family and society. Furthermore, this study examines the reasons through which women turned to prostitution on one hand, and to investigate Arab women's regression in achieving their complete rights on the other. During this study, we attempt to examine how Naguib Mahfouz addressed the issue of women extensively in various situations and on different social levels. Also, this study sheds light on how Mahfouz depicted the women who are subjected to exploitation and oppression. These women stand for the submissive wife, the sex object, the self-sacrificing women.
\end{abstract}

Keywords: feminism, female era, Naguib Mahfouz

\section{Introduction}

This research paper reveals the trends of Naguib Mahfouz and represents the novelist depiction of women in his well-known novels, which were originally written in the Arabic language and later translated into the English language by authentic translators. No doubt to say that Naguib Mahfouz is one of the most celebrated Arabic writers in the western world. He received the Nobel

i Correspondence: email balshami11@gmail.com 
Prize for literature in 1988 . He is described as a feminist writer delivering a multi-faceted critique on Egyptian society. Mahfouz is not only a creative writer, but he played a pivotal role in the growth and improvement of the Arabian literature. Arabic literary novel reached its climax by the effort of Naguib Mahfouz. When Naguib Mahfouz died, Egyptian president Hosni Mubarak, in a condolence meeting said that Mahfouz was a cultural light who brought Arabic literature to the world. Mahfouz is widely regarded as the founding father of the modern Arabic novel. As a pioneer character in Arabian literature, he discussed many issues related to the Arabian women and displayed the truth in which these women are suffering, he wrote from the depths of his society and depicted the anguish of his society. His works address the most pessimistic aspects of society; he measured as an amazing social critic who criticizes the traditions and customs in his society. Through his novels, Mahfouz describes the oppressive circumstances of women, who appear to view them as second class people. Mahfouz, as a socially responsible writer, tries to change society in all its aspects. Part of Mahfouz's aim in dealing with many females' stereotypes is to contribute to create awareness that makes women transcend the feeling of helplessness and passivity that he finds to be the key cause for their oppression. Mahfouz reveals, in his depiction of women, their real status in society. This research paper seeks answers to such questions like, how masculinity keeps its dominance over women. Does female character of Mahfouz challenge male authority? Why are women becoming prostitutes? And why Arab women have not yet earned their full rights?

\section{Feminism concept in Arabian world}

Arabic women in the Middle East are given less status than men. This can be attributed to the misinterpretation of religious constitution and traditions. In the mid-19th century, there were some improvements in this respect in the Arab world. The cycle of modernization, the penetration of Western civilization, and entering the Middle East by conquest, started to shift somewhat. The improvement in the role of women in society is one of the most important facets of the necessary reform. In several Arabic novels, the role played by female characters represents the dominant mind set towards women. Arab women were exposed to caste and class influences. Besides, the cycle of modernization between secular and religious impulses was subject to bitter experiences of colonialism. Hence, the most important element in the history of the Arab women's movement may have been its participation in the struggle for the emancipation of women within Arab societies. Consequently, the history of Arab women is split into two stages: the first explores the participation of the revolution in national emancipation, the second analyses the role of women in raising awareness of their own problems in post-independence. Scenario has diverse female characters: mothers, parents, slaves, friends, sisters, servants and so on, but the role of the sweetheart, passion or sex is the most important. They are loyal, submissive, dominant, autonomous, strong, and religious. The female characters of Mahfouz are passive, docile, submissive, and secondary to men who find these characteristics to be "normative and naturalized within the Egyptian society." Nevertheless, the present paper not only looks at the characters of Mahfouz's female as voiceless and helpless victims of subordinate society along with colonialism. It also represented poor women who could not surmount the obstacles. He has 
satirized people who react to women's new surprising positions in traditional fashion. He has illustrated Egyptian society's canvas that still tries to get the full image, either through proliferating character or by embedding a single character in a vibrant social background. We may say that he always writes as a feminist as he has opened up the deprived and frustrated lives of women in the rural parts of Cairo. 'Mahfouz 's women do not live in a different world where they individually suffer; his men and women are part of the same universe. They are trapped in mutually dependent relationships in which the actions of one affect the other. Mahfouz produces unforgettable characters that are admired or disliked by readers as if they knew them personally. Many are educated, some are illiterate, and some are significant, some are chaste, and some are loose. The topic of women in Mahfouz's fiction took a new turn when it was noticed that Mahfouz rarely allowed his female characters to exhibit their true femininity, keeping their interactions and emotions discreet, barely ever delving into the depths of their hearts and minds.

\section{The Obedient Women}

Mahfouz in Cairo Trilogy aims to reflect the reality of a male-dominated patriarchal culture in the Arab world that marginalizes women. This restrictive approach towards women in Arab society has had a negative effect on women's self-development and cultural positions. In the Cairo Trilogy, we can find various types of women, where Mahfouz portrays the oppression of women in a patriarchal society while capturing the fight for freedom and the confrontation between the Egyptian political powers. He also tells us the forms of husband-wife partnerships through married lives of various partners in the novel. Many of them are not based on love and are simply conventional partnerships where the husband is her lord. Mahfouz explores Egyptian culture's changing values through the story of the Alsyyids family and the advent of a new modern morality. He also discusses the diverse opinions of women that prevailed at the time. Al-Sayyid and his son Yaseen regard women mainly as child careers and a source of enjoyment. By claiming that they have the right to indulge a series of escapades every night and return to a quiet house and submissive wife at the end of the night, who is not even allowed to try respectfully protests against her husband's frequent nights out. Mahfouz tells us that the first wife of Alsyyid, Yaseen's mother, has been assaulted and then divorced because she objected to the actions of her husband. He married his second wife Amina, who became a synonym in the Arab world for the submissive woman. Amina is a slave who does all household tasks. She is reprimanded and not allowed even to express her opinions on family issues. Her duty is truly to please her lord and obey him no matter what her feelings or desires may be Mahfouz informs us that Amina thinks it's her duty as a married woman to follow her husband without any hesitation or condition. He is persuaded that real manhood, tyranny, and hanging out till midnight were the common characteristics of a single male. She's a lady whose thoughts are influenced by her husband. Even when the matter affects the future life of her children, she cannot voice her opinion on the matter because it is supposed to be the prerogative of her husband even if it ruins the lives of the family. She is a willing victim of stifling traditional practices that do not believe women should be assertive. As Mahfouz tells us, 
"No matter what happened, she remained a loving obedient and docile wife. She had no regrets at all about reconciling herself to a type of security based on surrender", (Mahfouz 1956 Palace Walk)

Al-Sayyid dictates to his two daughters that they should marry without considering that marriage is a matter of personal tendency. Because he believes, "no woman has a fully developed mind, he won't allow them to advise him on any matter. My opinion, says Amina to her husband, is the same as yours, sir. I have no opinion of mine" (Mahfouz 1956 Palace Walk; 156.2). Even when married and living in the homes of their husbands, his daughters still fear their father. Amina, completely unaware of the outside world, is convinced by her sons and daughters to go out and visit the AlHusayn mosque when AL-Sayyid is out of town. Mahfouz calls this excursion, an anti-patriarchy revolution similar to the 1919 revolution against the British. Amina has an overwhelming sense of wrong-doing. She has insecurity and a feeling of remorse. But she's eager to explore the outside world. (It is her pure joy to enjoy the independence movement of other living beings. "It is the pleasure of someone who has spent a quarter of a century imprisoned by the walls of her house" (Mahfouz 1956 Palace Walk; 168.3). When she has an accident, the truth is revealed to her husband. She is forced to leave the house for this slight error, after she heals fully, without being given the chance to justify why she left the house without his permission. Al-Sayyid has become a representation of the typical patriarch who has confined his wife to the house for a quarter of a century, leaving her husband's house to see her mother only on rare occasions. He follows her on each visit so no one should take a look at his wife. He believes he has a spiritual and ethical right to her and should handle her as he wants. Mahfouz criticizes Al-Sayyid for the unfair treatment of his wife and other family members. He is a decent and lovable person outside his home, whose company people seek. He shows modesty, integrity, and seriousness at home and unbridled sensuality between his friends and lovers. Although the women in his household are incarcerated, he enjoys complete freedom with several mistresses. As Amina hears her husband laughing with his friends one night as they return from their night outs, Mahfouz tells us (she and the children were accustomed from him to nothing but prudence, modesty, and gravity. How did he come across these happy, jesting sounds that came so joyfully and graciously out?

As a matter of facts, Mahfouz reveals that some men believe that women aren't comparable with them in power and intellect due to some outdated beliefs. It is this inflated feeling of dominance that leads men to refuse women from the right to such freedoms in life such as employment, jobs, and choosing partners. Any of them abuse women in their household while they manipulate women outside their households physically and emotionally.

\section{The Self-sacrificing Woman}

Here the word self-sacrificing is used to highlight the close connection between women's Circumstances and inequality. Mahfouz introduced a long list of prostitutes in his novels that he is explaining by them the state of abuse that women face in Cairo. It is the way to reveal the oppressive social and political climate in his country. These women are victims of socio-political circumstances that impact the entire country. It occurs in all social classes, but lower-middle- 
class women are more likely to witness violence. Yet women suffer doubly because they are the hostages of socio-economic circumstances and domination of men.

Mahfouz emphasizes that, prostitutes are not just falling women chasing desire and pleasure. Many of them are victims of unfair socio-economic structure leaving them with no other means of income. Man governs their lives and bodies because of their economic dependence on man. Many of Mahfouz's memorable female characters in his novels are prostitutes. Almost in every major novel of Mahfouz, one finds the prostitute. Example, Nafissa in the novel of Beginning and the End, she's attracted by sweet lies and deceptive words into a sly man hands. Her meagre profits from her job were eaten up by her family's urgent needs. Mahfouz tells us that, (she persuades herself that she accepts humiliation for the sake of money which her family badly needs. She finds pleasure, if we might call it that, in looking upon herself as a martyr and a victim of despondency and poverty, Mahfouz 1944:187. She works as a dressmarker to hide the real source of money she gives to family. Her financial support helps to make her younger brother, Hussein an officer in the army. Later, after she was caught in a brothel, her biggest worry was the poor name she would bring to her family, particularly to her brother. She begs him not to kill her because he's going to be charged and might lose his employment. She intentionally throws herself into the Nile to save her family from the humiliation. The penalty is severe, but we will remember that a person from Egypt behaves in the same way as Hussein. A dishonourable girl must be executed by her male family if they wish to continue living in that society. Unfortunately, while her male partner goes unpunished the girl is always punished. Even though Mahfouz wrote more than sixty years ago about Nafissa's tragedy, killing honour in most cultures of the Middle East is still a much alive problem.

\section{The Ambitious Women}

In Midaq Alley's novel, Mahfouz depicts the protagonist as ambitious young woman, aware of her beauty and her attractiveness. But her desire to flee the filthy life in the alley causes her to fall prey to sexual abuse by the same man she believed was her savior. Instead of finding a happy life, she is looking for; she ends up selling her body to men, especially British soldiers, as a prostitute in exploiter's brothel. In the Cairo Trilogy novel, we are given the struggle of uneducated and poor women (Zanuba), and her gradual growth from sex object to a respectable woman. She is a symbol of a conventional woman who becomes a victim of male abuse because she was born into a poor family. She is known to be the prostitute, though she does not choose Prostitution as a profession. She finds a way to avoid the humiliation of men and refuses to be Al-Sayyid and Yaseen's sex object; she uses her feminine charm to become Yaseen's wife and compel them to embrace her as part of their kin. She's turning into a loving wife and a devoted mother. Mahfouz, therefore, suggests that some fallen women can become respectable members of society if they have the opportunity to lead a life of dignity. Zanuba is a perfect example of the prostitute who finally surmounts her male tormentors. She pressures Al-Sayyid to confess her as the wife of his son, a proper member of his esteemed family, not as his plaything. 


\section{The New Woman}

Throughout the last part of the Trilogy Mahfouz reveals the near association between educational success and its preventive effects. Use awareness to educate women helps them escape violence. The writer sees schooling and equal incentives for jobs as a method for reaching the degree of economic freedom which he sees as a necessity for achieving equality. He opposes those who, like Al Sayyid, send their sons to schools and universities thereby depriving their daughters of the same opportunity. In Mahfouz's opinion, schooling and equitable job opportunities contribute to women's economic equality. He displays his conviction that women that are least educated are more likely to suffer violence. Most of his characters who are Victims of male violence and male treatment have little or no education at all. Their lack of education and economic dependence on men force people around them to exploit them. Mahfouz wants his society to realize that the culture of inequality and violence against women represents a major barrier to progress towards development.

Therefore, Mahfouz is seeking to drag women out of the limits of passive roles, traditionally prescribed and encouraging them to take more active roles in their society. Women in his fantasy world not only perform stereotypical roles such as singers, dancers, and submissive wives but also play a significant role in their country's history. Swsan Hamad emerging in Suger Street, the last part of the Cairo Trilogy, symbolizes the modern Egyptian woman who refuses to surrender to a male-dominated society. She also outstands in men through education and hard work. She steps out of her assigned feminine role and invades the domain of male work. She is the opposite of Amina and, from the novelist's point of view, her relationship with her husband and co-worker Ahmed I s the ideal male-female relationship in the Trilogy t. Only if women are no longer marginalized positive relationship become feasible. Sawsan is joining hands with her husband to accomplish the shared goal of the emancipation of their country. Mahfouz suggests gender equality is the cornerstone of any social evolution.

\section{Conclusion}

All in all, the representation of female characters in the novels mentioned in this paper reflects the feminism that Mahfouz seeks to explain and define the condition of Arab women. It is clearly mentioned that Mahfouz is a skilful artist who pictures the real image of the Arab society, especially Egyptian society, and how many movements such as feminism and modernism have influenced this society. He distinctly portrayed the populism of Egyptian society and described the misery faced by Arabian women. From the experiences of the characters described in this paper Mahfouz seeks to confirm self-realization and cultural awakening freedom from maledominance. This leads them to break society's norms and to prove their ability to change. Mahfouz's writing is important and gives voice to the countless women whose experiences were not heard, whose silence was silenced, and whose reputation was broken. Middle East men should be changing their attitude towards women. They should regard them as equal partners, not as domestic animals or sex objects. They have to accept women like men, have completely formed personalities, and can live without men's influence and strength. They must 
acknowledge the fact that the relationship between men and women is not a master-slave relationship, but a relationship of reciprocal dependency, in which each has rights and duties. Consequently, violence can be curtailed only by the method of education not just women but also men. Females should be mindful of their inherent strength and capacity to combat injustice and change their circumstances.

\section{Conflict of Interest Statement}

The authors declare no conflicts of interests.

\section{About the Authors}

Manal Hussein Ali Nukhrah is scholar student of PhD at School of literature and languages Swami Ramanand Teerth Marathwada University, Nanded, she is lecturer in Thamar university, Yemen, she has lectured as a visiting invited speaker internationally and has delivered numerous talks at international conferences and has conducted seminars with international audiences. She has published articles in journals.

Ali Naji Gahlan Muthanna is scholar student of $\mathrm{PhD}$ at School of literature and languages Swami Ramanand Teerth Marathwada University, Nanded, India, He has lectured as a visiting invited speaker internationally and has delivered numerous talks at international conferences and has conducted seminars with international audiences. He has published articles in journals. Mirza Sultan Biag is an Associate Professor \& Head Dept. of English, Indira Gandhi Sr. College. (IDCO), Nanded, India. He has lectured as a visiting professor/invited speaker internationally and has delivered numerous talks at international conferences and has conducted seminars with international audiences. He has published articles in journals.

\section{References}

Mahfouz, N. (1994). Palace walk (Vol. 1). Random House.

Palace of Desire: Cairo Trilogy II. Trans. William Maynard, Iorne M. Kenny, Olive E. Kenny. New York: Anchor Books, 1992. (First Arabic version 1957; First English Trans. 1991).

William Maynard Hutchins, Angele Botros Samaan. (1993), Sugar Street. Anchor Books, 1993. (First Arabic version 1957; First English Trans. 1992).

Lerner, G. (1986). The creation of patriarchy (Vol. 1). Oxford University Press, USA.

Abu-Haidar, J. A. (1996). Rasheed El-Enany: Naguib Mahfouz: the pursuit of meaning. 271 pp. London and New York: Routledge, 1993.£ 12.99. Bulletin of the School of Oriental and African Studies, 59(2), 349-352. Le

Gassick, T. (Ed.). (1991). Critical Perspectives on Naguib Mahfouz (Vol. 28). Lynne Rienner Publishers. 
Creative Commons licensing terms

Author(s) will retain the copyright of their published articles agreeing that a Creative Commons Attribution 4.0 International License (CC BY 4.0) terms will be applied to their work. Under the terms of this license, no permission is required from the author(s) or publisher for members of the community to copy, distribute, transmit or adapt the article content, providing a proper, prominent and unambiguous attribution to the authors in a manner that makes clear that the materials are being reused under permission of a Creative Commons License. Views, opinions and conclusions expressed in this research article are views, opinions and conclusions of the author(s). and European Journal of Literature, Language and Linguistics Studies shall not be responsible or answerable for any loss, damage or liability caused in relation to/arising out of conflicts of interest, copyright violations and inappropriate or inaccurate use of any kind content related or integrated into the research work. All the published works are meeting the Open Access Publishing requirements and can be freely accessed, shared, modified, distributed and used in educational, commercial and non-commercial purposes under a Creative Commons Attribution 4.0 International License (CC BY 4.0). 